\title{
Pre-operative carotid artery screening in patients undergoing coronary artery bypass grafting
}

\author{
Ana-Catarina Pinho-Gomes ${ }^{*}$, Rana Sayeed \\ From World Society of Cardiothoracic Surgeons 25th Anniversary Congress, Edinburgh \\ Edinburgh, UK. 19-22 September 2015
}

\section{Background/Introduction}

Stroke remains the major non-cardiac complication of coronary artery bypass surgery (CABG). Severe carotid artery disease is associated with a fourfold increase in the risk of post-operative stroke and this is the rationale for offering pre-operative carotid artery screening to these patients.

\section{Aims/Objectives}

We aim to assess the compliance with the ESC/EACTS guidelines for Myocardial Revascularisation (2014) regarding pre-operative carotid artery disease screening and estimate the clinical impact of adhering only to class-I evidence-based recommendations.

\section{Method}

The medical records of all the patients who underwent CABG in our unit between 1st November and 31st December 2014 were retrospectively reviewed.

\section{Results}

A total of 506 patients underwent CABG during the study period and 492 were included for analysis. 203 carotid artery Doppler ultrasound scans were performed. CAD screening was performed in 63/115 of the patients who met with class-I recommendations (history of stroke/transient ischaemic attack or carotid bruit) and $184 / 440$ of the patients who met with class-IIa recommendations (age over 70 years and/or peripheral artery disease and/or multi-vessel coronary artery disease).

There were 2 post-operative strokes, both in patients without CAD detected on pre-operative screening. Asynchronous carotid artery revascularisation was performed in 5 patients ( 4 prior to and 1 following CABG).

Department of Cardiac Surgery, John Radcliffe Hospital, Oxford, OX3 9AA, UK
Restricting carotid artery screening to class-I evidencebased recommendations criteria would have decrease the number of Doppler ultrasound scans from 203 to 115 , without missing patients with CAD who actually required revascularisation.

\section{Conclusion}

Adherence to class-I evidence-based recommendations for carotid artery screening would generate major efficiency savings and streamline pre-operative assessment of patients undergoing CABG.

Published: 16 December 2015

doi:10.1186/1749-8090-10-S1-A20

Cite this article as: Pinho-Gomes and Sayeed: Pre-operative carotid artery screening in patients undergoing coronary artery bypass grafting. Journal of Cardiothoracic Surgery 2015 10(Suppl 1):A20.
Submit your next manuscript to BioMed Central and take full advantage of:

- Convenient online submission

- Thorough peer review

- No space constraints or color figure charges

- Immediate publication on acceptance

- Inclusion in PubMed, CAS, Scopus and Google Scholar

- Research which is freely available for redistribution

Submit your manuscript at www.biomedcentral.com/submit
() Biomed Central 